\title{
En Torno a una Fotografía
}

Around a photograph

\section{Carlos Ayala-Gómez ${ }^{1}$}

A mis padres

$\mathfrak{C}$ uando era niño me encendía el espíritu recorrer los pasillos del Centro Comercial Camino Real, era para mí un placer inagotable. De la mano de mi mamá me detuve una vez frente a una vitrina de una elegante tienda de joyas del segundo piso, la fotografía enmarcada de un niño que cargaba sonriente dos botellas de vino me capturó el alma, no sabía entonces el porqué.

Antes de continuar la marcha había leído al pie de la imagen el apellido Cartier, y me hizo feliz conjeturar que aquel niño de apariencia modesta le había dado luego nombre a la fastuosa marca. El recuerdo se instaló en mí.

Los años que siguieron regresar a este lugar fue siempre visitar esa imagen, la que indemne al tiempo siguió conmoviéndome, mostrándome un glorioso instante de vida rescatado para siempre por la prodigiosa sensibilidad de un artista.

Muchos años después, antes de mi primera incursión en Europa, decidí tomar clases de fotografía sin otra pretensión que no fuera la de intentar registrar cabalmente cada instante que luego me tocara contar.

1 Máster en Derecho Corporativo. Lima, Perú.

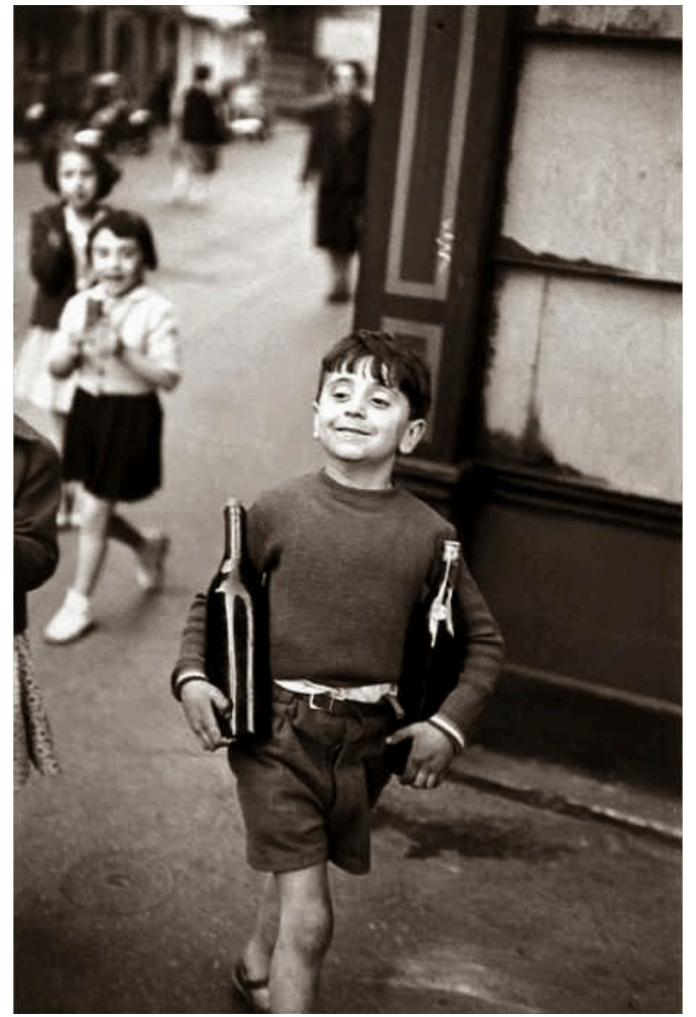

Rue Mouffetard, 1954. Henri Cartier-Bresson (1908-2004)

Una de esas mañanas de clase en Miraflores, mientras repasábamos la historia de la fotografía, el profesor proyectó en la blanca pared que teníamos al frente la imagen del niño sonriente llevando consigo las botellas de vino.

En mis ojos debe haberse leído una emoción desbordada, escuché entonces que la fotografía pertenecía a Henri Cartier-Bresson. 
Descubrí en ese momento que no era el Cartier de las joyas, labrado así por mi imaginación sino el Cartier para quien fotografiar consistía en retener el aliento y luego alinear la mente, la mirada y el corazón y, había añadido también, que uno sólo debía salir y esperar a que el mundo le regale algunas imágenes.
Hoy que escribo desde esta fría mañana de Madrid, advierto que ese niño de ocho años que algún día fui ya admiraba, sin saberlo, el gran talento de Cartier-Bresson.

Madrid, febrero 2020.

\section{CORRESPONDENCIA}

leyente1@hotmail.com

Fecha de recepción: 03-04-2020.

Fecha de aceptación: 05-08-2021 